\title{
Pemanfaatan Aplikasi Standar Pertumbuhan WHO 2005 Berbasis Smartphone Android (PSG Balita) terhadap Kualitas Data Gizi
}

\section{Utilization of WHO Growth Standards Application in 2005 Based on Android Smartphone (PSG Balita) on The Quality of Nutrition Data}

\author{
Agus Hendra Al Rahmad ${ }^{1}$, Junaidi ${ }^{2}$ \\ Jurusan Gizi, Politeknik Kesehatan Kemenkes Aceh, Indonesia
}

\section{ARTICLE INFO}

\section{Article history:}

Received date

27 Jan 2020

Revised date

24 Mar 2020

Accepted date

16 Apr 2020

Keywords:

Anthropometry standards;

Data quality;

Nutrition status;

PSG software.

\section{Kata kunci:}

Standar antropometri;

Kualitas data;

Status gizi;

Aplikasi PSG.

\author{
ABSTRACT/ ABSTRAK
}

The importance of fulfilling nutritional status information based on individuals can be fulfilled by using an online application system for recording and reporting community-based nutrition. The need for interventions to support nutritional surveillance through nutritional status monitoring activities can be carried out by name by address. The research objective was to make an assessment using a PSG Balita software can improve data and information quality of nutritional status. A quasi-Experimental research design needs to be done with Electronic and manual intervention on two districts involving 24 nutritionists at the public health center. Primary and secondary data was collected through an interview and observations using a questionnaire. The training in the treatment group by using the tool $a P S G$ Balita Software, and the control group used the book Kepmenkes RI No:1995/Menkes/SK/XII/2010. Information quality analysis is dependent on t-test and independent $\mathrm{t}$-test, using the $\mathrm{R}$. Intervention results of each group indicate increase the quality of nutrition information status ( $\mathrm{p}$-value $<0,05$ ). Group intervention use who anthro showing increased better ( $\mathrm{p}$-value $<0,05)$ than manual intervention. Besides, recording and reporting outputs model based on electronics can release more information, and useful in nutrition program planning, monitoring, and evaluation. The use of electronic-based systems is better quality and more data analysis outputs, both for monitoring planning and nutrition program evaluation as well as decisionmaking support.
Pentingnya pemenuhan informasi status gizi berdasarkan individu dapat terpenuhi dengan menggunakan sistem aplikasi online pencatatan dan pelaporan gizi berbasis masyarakat. Kebutuhan intervensi dalam penguatan surveilans gizi melalui kegiatan pemantauan status gizi (PSG) dapat dilakukan by name by address. Tujuan penelitian adalah untuk melakukan penilaian pengunaan aplikasi PSG Balita berbasis android dalam meningkatkan kualitas data dan informasi status gizi balita. Penelitian berdesain quasi experiment perlu dilakukan dengan intervensi elektronik dan manual pada dua kabupaten/kota, melibatkan 24 ahli gizi di Puskesmas. Data primer dan sekunder dilakukan secara wawancara dan observasi menggunakan kuesioner. Pelatihan menggunakan alat aplikasi PSG Balita berbasis android dan buku Kepmenkes RI No:1995/MENKES/SK/XII/2010. Analisis kualitas informasi yaitu Dependent T-Test dan Independent T-Test, menggunakan program R. Hasil intervensi masing-masing kelompok menunjukkan peningkatan terhadap kualitas informasi status gizi $(p$-vallue $<0,05)$. Kelompok intervensi menggunakan aplikasi PSG Balita menunjukkan peningkatan lebih baik $(p$-value $<0,05)$ dibandingkan intervensi manual. Selain itu, pencatatan dan model pelaporan berbasis elektronik dapat mengeluarkan output informasi yang lebih banyak, dan bermanfaat dalam perencanaan program gizi, monitoring dan evaluasi. Penggunaan sistem berbasis elektronik secara kualitas lebih baik, dan output analisis datanya lebih banyak, baik untuk perencanaan monitoring dan evaluasi program gizi maupun sebagai pendukung pengambilan keputusan.

Corresponding Author:

Agus Hendra Al Rahmad ${ }^{1}$, Junaidi ${ }^{2}$

Jurusan Gizi Politeknik Kesehatan Kemenkes Aceh, Indonesia.

${ }^{1}$ Email: 4605.ah@gmail.com

${ }^{2}$ Email: JunaidiNeidi@gmail.com 


\section{PENDAHULUAN}

Laporan pencapaian agenda pembangunan milenium menunjukkan Indonesia mencapai kemajuan yang tidak merata pada setiap indikator dimana tercapai untuk target tertentu, tertinggal pada target yang lain. Angka kematian balita dan bayi telah mengalami penurunan tajam tetapi masih belum mencapai target MDGs ditahun 2015 (Bappenas, 2015). Pemenuhan gizi pada anak balita merupakan faktor yang perlu diperhatikan dalam menjaga kesehatan, karena masa balita merupakan periode perkembangan yang rentan gizi. Balita merupakan kelompok masyarakat yang mengalami siklus pertumbuhan dan perkembangan yang membutuhkan zat-zat gizi lebih besar dari kelompok umur lainnya sehingga balita paling mudah menderita kelainan gizi (Dianingrum \& Suryanto, 2014). Persentase anak balita yang berstatus gizi kurang dan buruk serta permasalahan stunting masih belum bisa diatasi secara signifikan. Dengan demikian, situasi kesehatan di Indonesia menjadi pekerjaan rumah yang belum terselesaikan. Penekanan hal tersebut dituangkan dalam agenda pembangunan pasca 2015 yang secara spesifik termuat dalam RPJMN (Health, 2015).

Pembangunan dan target agenda pembangunan pasca 2015 yaitu pada tahun 2030, akan mengakhiri segala bentuk malnutrisi, termasuk mencapai target internasional 2025 untuk penurunan stunting dan wasting pada balita dan mengatasi kebutuhan gizi remaja perempuan, wanita hamil dan menyusui, serta lansia (Health, 2015). Menurut Nadiyah et al. (2014), Indonesia berdasarkan situasi gizi mempunyai disparitas yang tinggi antara setiap wilayah atau propinsi. WHO menetapkan besarnya suatu wilayah memiliki masalah gizi ringan (20-30\%) dan berat (>30\%). Berdasarkan laporan data Riskesdas bahwa Indonesia pada tahun 2018 masih bermasalah dengan underweight, stunting dan wasting. Hasil riset tersebut prevalensi balita underweight sebesar $17,7 \%$ terdiri dari $5,7 \%$ gizi buruk dan $13,9 \%$ gizi kurang. Begitu juga dengan prevalensi stunting, secara nasional tahun 2018 adalah $30,8 \%$. Selanjutnya balita dengan wasting, Indonesia tahun 2018 mempunyai prevalensi sebesar 10,2\% (Balitbangkes, 2018). Walupun terjadi penurunan prevalensi masalah gizi dari tahun 2013, namun angka tersebut belum begitu signifikan (Miko \& Al-Rahmad, 2017).

Status gizi balita di Provinsi Aceh, berdasarkan data Riskesdas 2018 (Balitbangkes,
2018), menunjukkan bahwa kondisinya belum membaik yaitu tingginya kasus gizi kronis akut pada balita secara khususnya. Terdapat sebesar $23,5 \%$ balita yang mengalami masalah gizi kurang dan gizi buruk (underweight) dan sebesar $11,9 \%$ kekurusan atau wasting. Selanjutnya prevalensi stunting masih sangat tinggi yaitu mencapai sebesar $37,3 \%$ dan menduduki peringkat ketiga setelah Sulawesi Barat $(41,8 \%)$ dan NTT $(42,6 \%)$. Sedangkan prevalensi pada anak dibawah dua tahun (baduta), Aceh mempunyai prevalensi paling tinggi yaitu sebesar $18,9 \%$, dan hal yang sama juga terjadi pada tahun 2013 (19,0\%).

Suatu kegiatan Pemantauan Status Gizi (PSG) diperlukan suatu penilaian terhadap status gizi yang bersumber dari baku rujukan, oleh karena itu dalam menilai besarnya masalah gizi suatu populasi perlu penggunaan indikator status gizi (AL-Rahmad \& Sudargo, 2016). Mendukung pengambilan keputusan tersebut, pengembangan data serta sistem informasi kesehatan pada setiap daerah terhadap tenaga kesehatan menjadi sangat penting dan harus didukung oleh kemajuan teknologi informasi (Randell et al., 2009). Menurut Ganeshkumar et al. (2011), bahwa pencatatan dan pelaporan merupakan indikator keberhasilan suatu kegiatan, tanpa itu apapun bentuk program gizi yang dilakukan manfaatnya kurang baik. Pendapat tersebut diperkuat oleh Bara et al. (2009) ternyata informasi yang tepat waktu, kelengkapan dan keakurasian yang tinggi dapat meningkatkan proses pelayanan kesehatan, hal tersebut dapat tercapai melalui pemanfaatan kemajuan teknologi dan informasi.

Keberhasilan pembangunan kesehatan sebagaimana yang dimaksud dalam Sistem Kesehatan Nasional (SKN) diperlukan manajemen kesehatan yang baik dengan dukungan ketersediaan data serta informasi kesehatan yang relevan, tepat waktu, akurat dan sesuai dengan kebutuhan program kesehatan. Kebutuhan informasi kesehatan tersebut mencakup seluruh data dari berbagai sektor kesehatan, khususnya data gizi maupun sektor lainnya (Wardani \& Astuti, 2017).

Sumber daya manusia sangat mempengaruhi program kerja, rendahnya kualitas sumber daya manusia menjadi faktor penghambat berhasilnya program pemantauan dan pertumbuhahan balita (Mason et al., 2010). Ketersediaan sumber daya manusia yang berkualitas merupakan modal pembangunan nasional suatu bangsa. Hal ini dapat terjawab melalui pembangunan sumber daya manusia yang sehat, tangguh fisik dan mental, serta 
cerdas (Sartika, 2012). Peningkatan kinerja dan performance sistem pelaporan dan informasi pemantauan status gizi diperlukan pengembangan sistem informasi berbasis komputer, untuk menghasilkan kegiatan secara lebih lengkap, cepat dan penyajian data berupa pemetaan berdasarkan indikator cakupan gizi (Wajhillah \& Pribadi, 2014).

Pengembangan data serta sistem informasi kesehatan adalah sebagai pendukung pengambilan keputusan manajemen baik perbaikan pelayanan maupun program kesehatan secara langsung (Sanjaya \& Hidayat, 2016). Menurut (Ford et al., 2016), bahwa indikator terhadap keberhasilan informasi dimulai dari bagusnya data pencatatan dan pelaporan suatu kegiatan. Hasil dari pencatatan dan pelaporan merupakan sebuah data dan informasi yang berharga dan bernilai bila menggunakan metode yang tepat dan benar. Lebih lanjut (Guyon et al., 2016) menyimpulkan bahwa informasi yang tepat waktu, kelengkapan dan keakurasian yang tinggi dapat meningkatkan proses pelayanan kesehatan, akan tetapi kenyataan di lapangan hal tersebut masih jarang dijumpai seperti data yang tidak lengkap, informasi yang terpisah serta tidak pada waktunya.

Mengingat pentingnya pemenuhan informasi status gizi berdasarkan individu dapat terpenuhi dengan menggunakan sistem aplikasi online, maka pencatatan dan pelaporan gizi haruslah berbasis masyarakat. Keterbaruan dalam studi ini yaitu diperolehnya suatu kualitas informasi data status gizi balita dengan menggunakan smartphone android. Sehingga, kebutuhan intervensi dalam penguatan surveilans gizi melalui kegiatan pemantauan status gizi (PSG) dapat dilakukan by name by address dan dapat menjawab kebutuhan data dalam penanggulangan masalah gizi. Tujuan penggunaan agar tenaga pelaksana gizi dan pemangku kebijakan di daerah lebih mudah dalam mengamati permasalahan gizi di wilayah mereka untuk selanjutnya mengambil keputusan terhadap dan tindakan apa yang akan dilakukan, baik secara komunitas maupun individu (Al Rahmad et al., 2013).

\section{METODE}

Penelitian ini menggunakan desain Research and Development ( $\&$ D) dengan tujuan untuk mengembangkan produk berupa mobile aplication berbasis Android untuk menunjang pelaksanaan kerja tenaga gizi dalam penentuan status gizi balita. Pendekatan kuantitaf juga dilakukan yang bertujuan untuk menilai hasil dari pengembangan aplikasi PSG Balita yang dikaji kefektifannya pada pengguna. Penelitian ini telah dilakukan di Wilayah Kota Banda Aceh, mengingat masih tingginya data malnutrisi di Aceh baik data terkait underweight, wasting maupun stunting. Sedangkan waktu pelaksanaan penelitian yaitu dimulai pada Juni-Oktober 2019. Jumlah subjek yang terlibat yaitu sebanyak 24 orang tenaga gizi yang diambil secara proporsional berdasarkan tempat bekerja baik pada dinas kesehatan maupun puskesmas. Pengambilan sampel berdasarkan kriteria inklusi, yaitu ahli gizi, pendidikan minimal D-III Gizi, status sebagai PNS, sebagai penanggung jawab gizi. Sedangkan kriteria eksklusi yaitu penanggung jawab gizi tetapi bukan ahli gizi dan tidak berpendidikan minimal D-III gizi, status pegawai kontrak atau tenaga honor.

Tahapan penelitian yang akan dilakukan yaitu mengacu pada metode Research and Development dengan menggunakan pendekatan Waterfall model. Aplikasi PSG Balita dikembangkan melalui tahapan prototyping model terdiri dari kebutuhan sistem, perancangan dan pengimplementasian aplikasi, mengevaluasi aplikasi.

Setelah mendapakan keterangan kelayakan etik (Ethical Approval) dengan Nomor: LB.02.03/3095/2019 dari Komisi Etik Penelitian Kesehatan (KEPK), maka selanjutnya dilakukan pengumpulan dan pengolahan data secara triangulasi, yaitu membandingkan data yang diperoleh dari hasil wawancara dan observasi untuk mendapatkan konsistensi, ketuntasan dan kepastian data. Kualitas data informasi yang dibandingkan meliputi aspek tepat waktu, kelengkapan, keakuratan, dan manfaat. Data dikumpulkan melalui FGD dan wawancara langsung, kemudian diolah secara komputerisasi dengan melewati beberapa tahapan yaitu, editing (pemeriksaan data), coding (pemberian kode), entry (pemasukan data komputer), cleaning data entry.

Tahapan analisis yang dilakukan terdiri dari tahap reduksi data (data reduction), pengujian inferensial serta, penyajian data (data display), dan penarikan kesimpulan (conclusion: drawing/verifying). Secara inferensial, analisis data menggunakan software statistik $\mathrm{R}$ bersifat open source. Uji yang digunakan yaitu Dependent T-Test dan Independent T-Test pada CI: $95 \%$. 


\section{HASIL}

\section{Karakteristik Responden}

Penelitian dilakukan pada 11 puskesmas dalam wilayah Dinas Kesehatan Kota Banda Aceh, semua Puskesmas diikutsertakan dalam unit analisis serta diambil sebanyak 22 subjek dan 2 subjek dari Dinas Kesehatan. Adapun karakteristik subjek penelitian menurut kelompok penelitian disajikan pada Tabel 1, meliputi aspek umur, jenis kelamin, pendidikan dan pelatihan.

Berdasarkan karakteristik responden (tabel 1), menunjukkan secara umum responden berusia 35-50 tahun (62,5\%) dan berjenis kelamin perempuan $(79,2 \%)$. Sedangkan berdasarkan latar belakang pendidikan umumnya sudah berpendidikan D-IV gizi atau dibidang kesehatan yang relevan yaitu sebesar $41,7 \%$ serta sebesar $83,3 \%$ responden dalam penelitian ini telah mengikuti pelatihan terkait gizi.

\section{Tabel 1. Distribusi Karakteristik Responden}

\begin{tabular}{lrr}
\hline \multirow{2}{*}{ Karakteristik Subjek } & \multicolumn{2}{c}{ Frekuensi } \\
\cline { 2 - 3 } & n & \% \\
\hline Umur & 9 & 37,5 \\
25-34 tahun & 15 & 62,5 \\
35-50 tahun & 5 & 20,8 \\
Jenis Kelamin & 19 & 79,2 \\
Laki-Laki & 7 & 29,2 \\
Perempuan & 10 & 41,7 \\
Pendidikan & 5 & 20,8 \\
D-III Gizi/Kesehatan & & 8,3 \\
D-IV Gizi/Kesehatan & & \\
S-1 Gizi/Kesehatan & & \\
S-2 Gizi/Kesehatan & 2 & 83,3 \\
Pelatihan Gizi & & \\
Ya & 20 & 16,7 \\
Tidak & 4 & \\
&
\end{tabular}

\section{Kebutuhan Data pada Aplikasi PSG Balita}

Aplikasi PSG Balita dikembangkan untuk menjawab problematika kesehatan khususnya bidang gizi di lingkungan masyarakat. Pembuatan aplikasi ini berbasis android didasari oleh permasalahan keseharian masyarakat adalah banyak orang yang masih sering ditemukan masyarakat menengah ke bawah masih kekurangan gizi yang parah, khususnya masih tingginya kasus stunting dan wasting serta gizi buruk pada balita di Provinsi Aceh. Hasil dari Focus Group Disscussion (FGD) kebutuhan yang utama adalah faktor kemudahan, sebagaimana kutipan berikut:

\footnotetext{
"Menggunakan program WHO Anthro yang sekarang kami gunakan untuk mengitung data PSG sangat susah, karena
}

harus dikonversi kedatabase. Kami lebih mudah dan nyaman menggunakan Microsoft Excel. Sebaiknya data dasar untuk ekspor yang digunakan adalah berbasis Microsoft Excel."

Lebih lanjut hasil diskusi menemukan bahwa, pada berbagai aplikasi gizi sangat banyak indikator yang ditampilkan serta berbahasa inggris, dan hasil interpretasi hanya menampilkan nilai $z$-score serta kode warna. Kondisi inisangat mempengaruhi presisi dan akurasi terkait hasil interpretasi dari TPG dilapangan.

"Saat ini kami telah menggunakan aplikasi WHO Anthro yang pernah dilatih, tetapi sulit bagi kami dalam melakukan pekerjaan sehari-hari. WHO Anthro tersebut tidak bisa menyajikan data lebih rinci, misalnya data jumlah anak berdasarkan jenis kelamin, berapa anak gizi buruk, jumlah anak yang pendek, serta informasi data lainnya. Kami megharapkan Aplikasi PSG ini dapat memberikan hasil statistik seperti jumlah anak menurut jenis kelamin, prevalensi gizi kurang dan gizi buruk, prevalensi anak pendek, dan lain sebagainya. Kami rasa ini akan sangat bermanfaat dalam pelaporan data dari Puskesmas ke Dinas Kesehatan."

"Pada Aplikasi WHO Anthro terdapat modul yang sangat bagus yaitu Anthropoetric Calculator, sebaiknya pada aplikasi PSG Balita ini juga dimuat modul tersebut. Akan menjadi lebih bagus bila aplikasi PSG Balita juga menyertakan fitur-fitur grafik pada setiap indikator dalam menghitung data status gizi balita."

Selain itu, juga pelengkap dari aplikasi disediakan suatu fitur atau Modul yang hanya menyediakan fasilitas untuk melakukan penilaian status gizi anak secara individu. Indeks penilaian gizi sangat lengkap yaitu meliputi semua indeks yang ada dalam standar pertumbuhan WHO seperti indikator $\mathrm{BB} / \mathrm{U}$; TB/U; $\mathrm{BB} / \mathrm{TB}$; IMT/U; $\mathrm{LLA} / \mathrm{U} ; \mathrm{LK} / \mathrm{U}$. Untuk memudahkan interpretasi data, pada modul ini disediakan grafik $z$-score.

\section{Struktur dan Sistem pada Aplikasi PSG Balita}

Struktur menu aplikasi, selain memiliki halaman administrator, sebuah aplikasi memiliki halaman pengunjung. Halaman pengunjung merupakan halaman yang dapat diakses oleh semua pengunjung dan menjadi halaman inti dari 
sebuah aplikasi. Pada aplikasi yang dikembangkan, fitur tersebut dapat diakses dengan alamat melalui aplikasi. Halaman pengunjung memiliki Menu Home, Kalkulator Gizi, dan Buat Akun serta Menu Bantuan. Berikut disajikan struktur menu halaman pengunjung.

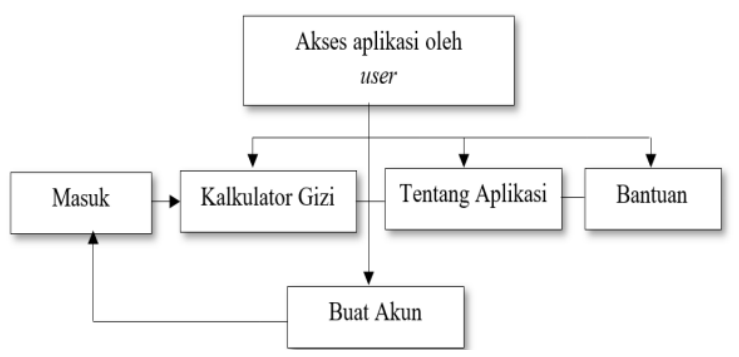

Gambar 1. Struktur Menu Halaman Aplikasi PSG Balita

Pengunjung dapat melihat halaman depan (home) dan mencoba fitur yang ada pada aplikasi. Namun, jika pengunjung ingin menggunakan fitur Survei Status Gizi dan profil harus terlebih dahulu melakukan registrasi (daftar) melalui proses pembuatan akun. Setelah mendaftar, user dapat melakukan validasi username dan password dengan cara login pada menu yang tersedia. Hal ini bertujuan agar setiap pengunjung memiliki satu username keanggotaan.

Interface pada aplikasi PSG Balita didesain mengutamakan User Interface yang baik yaitu sebuah interface yang mudah dimengerti dan simple. Selain itu, user interface harus memberikan sebuah kemudahan bagi useruntuk dapat berinteraksi dengan program atau aplikasi. Aplikasi dikembangkan sebagai bentuk kemudahan kepada user yaitu tenaga pelaksana gizi di Puskesmas serta masyarakat pada umumnya. Aplikasi ini bersifat online di Smartphone Android dan dapat juga diakses pada website dengan url: https://psgbalita.com/. Berikut tampilan utama aplikasi PSG Balita.
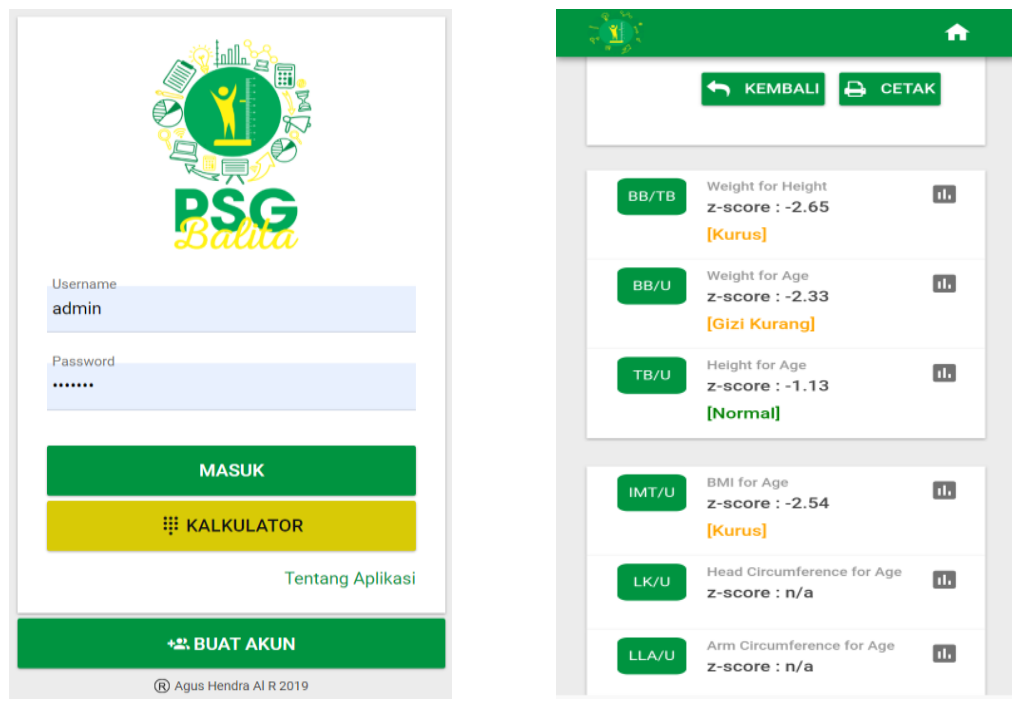

Gambar 2. Interface Awal Aplikasi PSG Balita

\section{1.: :...PSG Balita}

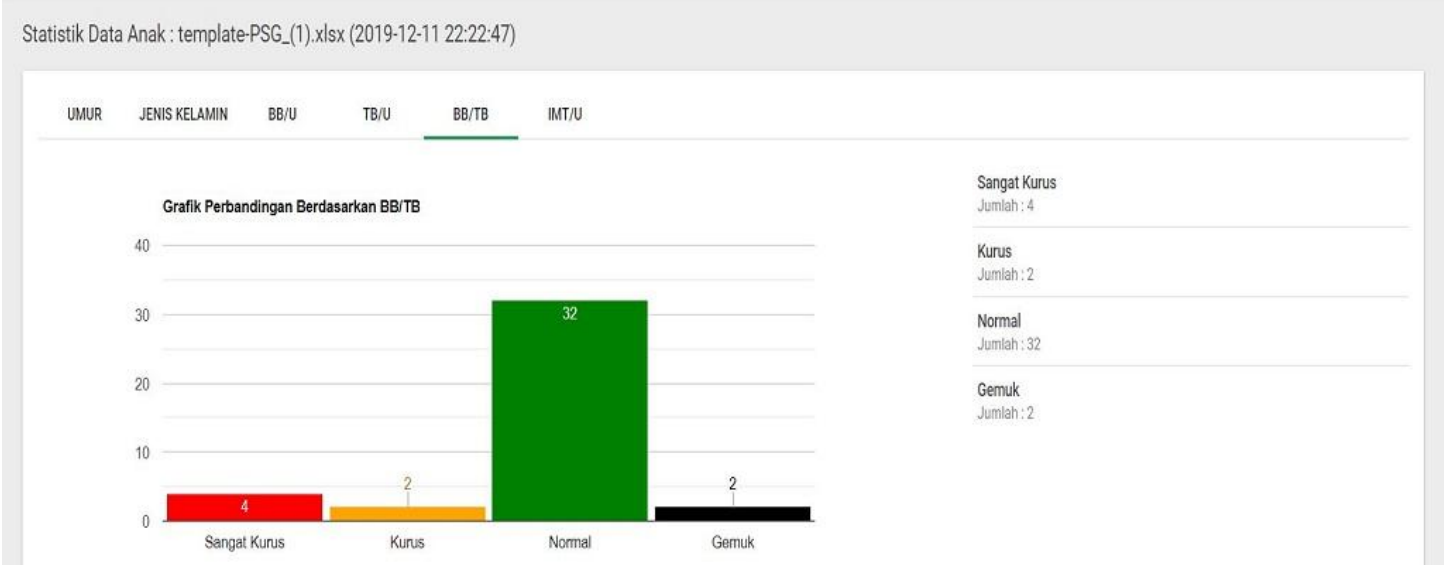

Gambar 3. Interface Analisis Statistik Aplikasi PSG Balita 
Pengaruh Penerapan Aplikasi PSG Balita terhadap Kualitas Data Status Gizi

Pencapaian peningkatan kualitas data gizi, kualitas data gizi selama penerapan aplikasi PSG Balita setelah satu bulan mempunyai peningkatan yang baik terutama aspek tepat waktu, aspek kelengkapan, dan aspek keakuratan. Secara deskriptif pelatihan tentang penggunaan aplikasi PSG Balita selama satu bulan penerapannya dapat meningkatkan kualitas informasi data status gizi balita.

Secara statistik, berdasarkan hasil penelitian sebagaimana disajikan pada Tabel 2 dapat dibuktikan bahwa setelah satu bulan pelatihan dan penerapan aplikasi PSG Balita, menunjukkan persentase kualitas informasi data status gizi balita mencapai sebesar 18,5\% (ketepatan waktu, 22,0\% (kelengkapan), 7,5\% kekakuratan, dan 6,0\% dari segi manfaat. Semua aspek kualitas informasi data status gizi balita (ketepatan waktu, kelengkapan, keakuratan, dan manfaat) setelah pelatihan dan penerapan selama satu bulan menunjukan perbedaan sangat signifikan $(p$-value $<0,05)$ pada tenaga pelaksana gizi (TPG) dalam wilayah Dinas Kesehatan Kota Banda Aceh.

Tabel 2. Pengaruh Penerapan Aplikasi PSG Balita Kualitas Data Gizi

\begin{tabular}{|c|c|c|c|c|}
\hline \multirow{3}{*}{ Aspek Kualitas Informasi } & \multicolumn{4}{|c|}{ Penerapan Aplikasi PSG Balita } \\
\hline & \multicolumn{2}{|c|}{ Pretest - Posttest 1} & \multicolumn{2}{|c|}{ Posttest 1 - Posttest 2} \\
\hline & $\Delta M e a n \pm S D$ & $p$-value & $\Delta M e a n \pm S D$ & $p$-value \\
\hline Tepa & $2,3 \pm 5,49$ & $0,0828^{*}$ & $18,5 \pm 8,13$ & 0,0000 \\
\hline Kelengkapan & $11,0+5,98$ & 0,0001 & $22,0+4,10$ & 0,0000 \\
\hline Keakuratan & $12,3 \pm 7,86$ & 0,0012 & $7,5 \pm 4,44$ & 0,0004 \\
\hline Manfaat & $2,3 \pm 3,02$ & 0,0035 & $6,3 \pm 5,82$ & 0,0001 \\
\hline
\end{tabular}

Tabel 3. Kualitas Data Gizi Memanfaatkan Aplikasi PSG Balita

\begin{tabular}{|c|c|c|c|c|c|c|}
\hline \multirow{3}{*}{$\begin{array}{c}\text { Aspek Kualitas Informasi } \\
\text { Data }\end{array}$} & \multicolumn{6}{|c|}{ Implementasi dan Penerapan Aplikasi PSG Balita } \\
\hline & \multicolumn{2}{|c|}{ Sebelum penerapan } & \multicolumn{2}{|c|}{ Setelah penerapan } & \multicolumn{2}{|c|}{1 bulan penerapan } \\
\hline & Mean $\pm S D$ & p-value & $M e a n \pm S D$ & p-value & Mean $\pm S D$ & p-value \\
\hline \multicolumn{7}{|l|}{ Tepat Waktu } \\
\hline Aplikas & $62,8 \pm 7,52$ & 0,050 & $65,0 \pm 6,28$ & 0,012 & $83,5 \pm 8,75$ & 0,000 \\
\hline Manual (Buku & $57,5 \pm 8,81$ & & $58,8 \pm 8,56$ & & 6,79 & \\
\hline \multicolumn{7}{|l|}{ Kelengkapan } \\
\hline Aplikasi PSG E & $60,3 \pm 6,78$ & 0,031 & 71,3 & 0,027 & $93,3 \pm 5,20$ & 0,000 \\
\hline Manual (Bu & $64,5 \pm 5,10$ & & $66,8 \pm 6,13$ & & $68,3 \pm 6,13$ & \\
\hline \multicolumn{7}{|l|}{ Keakuratan } \\
\hline Aplikasi PSG Balita & $74,8 \pm 6,78$ & $0,427 *$ & $87,0 \pm 7,50$ & 0,001 & $94,5 \pm 5,10$ & 0,000 \\
\hline Manual & $73,0 \pm 6,96$ & & $74,8 \pm 5,73$ & & $78,8 \pm 6,46$ & \\
\hline \multicolumn{7}{|l|}{ Manfaat } \\
\hline Aplikasi PSG Balita & $85,5 \pm 6,67$ & $0.297 *$ & $87,8 \pm 5,96$ & $0,512 *$ & $94,0 \pm 5,03$ & 0,034 \\
\hline Manual (Buku PSG) & $87,8 \pm 6,78$ & & $89,0 \pm 5,98$ & & $90,3 \pm 5,73$ & \\
\hline
\end{tabular}

Kualitas informasi data status gizi balita (Tabel 3) menunjukan peningkatan nilai rata-rata antara sebelum penerapan, setelah penerapan aplikasi PSG Balita sampai dengan satu bulan penerapannya. Selain itu, kualitas informasi pada kelompok perlakuan lebih tinggi nilai rataratanya dibandingkan dengan kelompok kontrol. Selisih rata-rata persentase kualitas informasi data gizi diantara kedua kelompok yaitu menunjukkan peningkatan antara sebelum pelatihan, setelah pelatihan dan satu bulan setelah pelatihan. Pengukuran efektivitas penerapan aplikasi PSG Balita ternyata, setelah satu bulan dilakukan pelatihan dan penerapan antara berbasis aplikasi android dengan manual menunjukan kualitas informasi data gizi yang menggunakan aplikasi PSG Balita berbais android mempunyai efektivitas lebih baik dibandingkan menggunakan pengukuran status gizi secara manual $(p$-value $<0,05)$.

\section{PEMBAHASAN}

\section{Aplikasi PSG Balita}

Tahapan penentuan kebutuhan data dalam melakukan pengolahan data status gizi balita terhadap kemudahan akses serta pemakaian oleh tenaga gizi di Puskesmas (TPG), menurut (Dianingrum \& Suryanto, 2014) bahwa aplikasi berbasis android belum ada yang digunakan untuk melakukan analisis terhadap pemantauan status gizi balita, beberapa aplikasi yang sudah 
dikembangkan cenderung digunakan untuk melakukan penilaian status gizi secara individu. Dibandingkan aplikasi WHO Anthro, ketika digunakan dalam mengeksport database relatif menyulitkan karena data yang di eksport harus dilakukan konversi ke .dbf atau .csv dan ini menurut TPG sedikit merasa kesulitan. Menurut Lwoga (2014), menyatakan bahwa tingkat kepuasan dari user terhadap sistem informasi berbasis aplikasi web berpengaruh terhadap kesediaan dalam melanjutkan penggunaan sistem tersebut untuk memenuhi kebutuhan informasi. Randell et al. (2009) menyimpulkan dalam mengolah data diperlukan suatu peralatan yang bisa meningkatkan pemahaman serta aksebilitas yang tinggi dan ini merupakan sesuatu hal yang sangat lazim dilakukan oleh perangkat elektronik seperti android, komputer dan perangkat lainnya.

Setiap proses pengambilan keputusan minimal membutuhkan satu kriteria atau lebih sebagai bentuk alternatif keputusan melalui pembobotan sehingga akan terintegrasi kedalam sistem yang sebelum telah diciptakan (Ganeshkumar et al., 2011). Sistem tergantung pada sumber daya manusia (pengguna akhir dan pelaksana sistem informasi), perangkat keras (hardware), perangkat lunak (soffware), data (data dan pengetahuan dasar) dan jaringan yang melakukan proses pemasukkan, pemrosessan, pengeluaran penyimpanan dan aktifitas pengendalian yang mengubah data mentah menjadi suatu hasil berupa informasi (Weiskopf \& Weng, 2013).

Hasil penelitian Buntin et al. (2011), telah menyatakan bahwa suatu kemajuan teknologi informasi kesehatan dapat meningkatkan kemampuan dalam hal efisiensi dan mutu dari proses kerja. Kemampuan generalisasi serta tingkat keefektivitasan tersebut menjadi sangat penting dalam bidangnya karena sistem teknologi informasi kesehatan merupakan sebuah tool dalam mendukung proses pelayanan kesehatan. Lebih lanjut menurut Faber et al. (2009), keberadaan aplikasi dalam mendukung informasi kesehatan berkaitan dengan peningkatan kapasitas dan kemampuan serta proses penguatan manajemen yang baik akan sangat membantu dalam meningkatkan cakupan pelayanan kesehatan serta didukung oleh penggunaan fasilitas yang baik. Akan tetapi sebaliknya, lemahnya struktur organisasi, proses dan kurangnya pengetahuan dan keterampilan dalam manajemen pelayanan kesehatan menjadi faktor dasar yang menghambatnya pemberian pelayanan kesehatan.

Aplikasi PSG Balita telah diimplementasikan pada tenaga pelaksana gizi di
Kota Banda Aceh. Model yang digunakan adalah melalui Blackbox testing. Menurut Nidhra dan Dondeti (2012), blackbox testing adalah menguji perangkat lunak dari segi spesifikasi fungsional tanpa menguji desain dan kode program. Pengujian dimaksudkan untuk mengetahui fungsi-fungsi, masukan, dan keluaran dari perangkat lunak sesuai dengan spesifikasi yang dibutuhkan. Pengujian kotak hitam dilakukan dengan membuat kasus uji yang bersifat mencoba semua fungsi dengan memakai perangkat lunak apakah sesuai dengan spesifikasi yang dibutuhkan. Kasus uji yang dibuat untuk melakukan pengujian blackbox testing harus dibuat dengan kasus benar dan kasus salah.

\section{Pengaruh Penerapan Aplikasi PSG Balita dan Kualitas Data Gizi}

Penerapan aplikasi PSG Balita berpengaruh sgnifikan terhadap kualitas data gizi, selain itu aplikasi PSG Balita juga mempunyai efektifitas yang baik dalam menghasilkan kualitas data gizi yaitu lebih spesifik ke kualitas data status gizi balita di Kota Banda Aceh. Hasil penelitian didukung oleh penelitian lain seperti (Buntin et al., 2011) keberadaan aplikasi teknologi kesehatan berdampak terhadap peningkatkan mutu dan kualitas proses kerja, selain itu meningkatkan nilai efisiensi. Peningkatan ini dimulai dari pemahaman dan respon positif serta mempunyai kemampuan generalisasi, dan nilai tingkat keefektivitasan tersebut menjadi sangat penting. Selain itu didukung oleh Bara et al. (2009) yang menyimpulkan, peningkatan kemampuan tenaga kesehatan dilapangan tidak hanya dengan membaca, tetapi untuk meningkatkan pemahaman dan persepsi mereka lebih baik melalui suatu bentuk kegiatan pelatihan atau penerapan teknologi.

Jones et al. (2014), menyatakan bahwa kualitas data sangat tergantung pada banyaknya keinginan pengguna dalam menggunakan data. Para ahli menganggap bahwa melalui teknologi informasi akan meningkatkan efesiensi dan kualitas dalam pelayanan kesehatan. Berarti data yang diinginkan harus akurat, tepat waktu, relevan, lengkap, mudah dipahami dan dapat dipercaya. Menurut Chaudhry et al. (2006) suatu teknologi informasi kesehatan dapat menunjukan kemampuan terhadap peningkatkan efisiensi dan mutu proses kerja, dimulai dari pemahaman dan respon positif serta tingkat keefektivitasan tersebut menjadi sangat penting.

Kemajuan teknologi informasi di bidang kesehatan dalam meningkatkan kualitas data 
dapat dicapai dan memberikan manfaat yang positif, selain itu efesiensi dari biaya juga dapat ditekankan. Seyogianya suatu program pembelajaran harus ditingkatkan pada pelatihan yang bersifat formal untuk menghasilkan suatu informasi yang berkualitas, juga kapasitas tenaga kesehatan semakin baik dan bermutu dalam bekerja (Erwin, 2008).

Pelatihan dan penerapan berbasis android menggunakan Aplikasi PSG Balita sebagai bentuk pengembangan sumber daya manusia mempunyai misi dalam memaksimalkan efektivitas TPG Puskesmas untuk melaksanakan tugas pokok dan fungsinya sebagai ahli gizi dalam melayani masyarakat. Selain itu, dimaksudkan juga bahwa tujuan dalam pelatihan dan penerapan aplikasi ini untuk memberikan informasi-informasi terbaru terkait dengan penggunaan standar pertumbuhan WHO-2005 serta meningkatkan komitmen dalam berorganisasi melalui perubahan kognitif individu tenaga gizi di Puskesmas dalam wilayah Kota Banda Aceh.

\section{SIMPULAN}

Pemanfaatan aplikasi PSG Balita berdampak positif dan mempunyai pengaruh signifikan terhadap peningkatan kualitas data gizi khususnya data status gizi balita. Sedangkan dari nilai efektifitasnya, penerapan aplikasi PSG Balita berbasis android mempunyai nilai kualitas yang leih baik dibandingkan dengan penggunaan buku PSG secara konvensional. Selain itu, penggunaan sistem berbasis elektronik (aplikasi PSG Balita berbasis android) secara kualitas lebih baik, dan output analisis datanya lebih banyak, baik untuk perencanaan monitoring dan evaluasi program gizi maupun sebagai pendukung pengambilan keputusan dalam penanganan masalah-masalah gizi di Kota Banda Aceh.

Penerapan hanya dilakukan selama satu bulan, sehingga pihak dinas kesehatan perlu melakukan observasi dan evaluasi lebih lanjut dalam memaksimalkan tenaga gizi untuk menggunakan aplikasi PSG Balita. Selain itu, pada pengembangan aplikasi ini hanya disediakan modul kalkulator gizi dan survei gizi, sehingga saran kedepan perlu pengembangan lanjutan untuk menambahkan modul pertumbuhan untuk dapat memantau laju tumbuh kembang anak secara antropometri.

\section{DAFTAR PUSTAKA}

AL-Rahmad, A. H., \& Sudargo, T. (2016). Efektivitas Pelatihan Standar Pertumbuhan WHO Anthro terhadap Kualitas dan Informasi Data Status Gizi Balita. Journal of Information Systems for Public Health, 1(1), 39-46.

Al Rahmad, A. H., Sudargo, T., \& Lazuardi, L. (2013). The Effectiveness Of WHO Anthro Growth Standard Training On The Data Quality Of Underfive Children's Nutritional Status. Journal of Information Systems for Public Health, 1(1), 21-26.

Balitbangkes Kemenkes, R. I. (2018). Riset Kesehatan Dasar 2018 (Riskesdas 2018). Kemenkes RI, Jakarta.

Bappenas. (2015). Laporan Pencapaian Tujuan Pembangunan Milenium di Indonesia 2014 (B. P. P. Nasional, Ed. Kesembilan ed.). Kementerian Perencanaan Pembangunan Nasional. http://sekretariatmdgs.or.id/?p=1434

Bara, D., McPhillips-Tangum, C., Wild, E. L., \& Mann, M. Y. (2009). Integrating child health information systems in public health agencies. Journal of public health management and practice, 15(6), 451-458.

Buntin, M. B., Burke, M. F., Hoaglin, M. C., \& Blumenthal, D. (2011). The benefits of health information technology: a review of the recent literature shows predominantly positive results. Health affairs, 30(3), 464471.

Chaudhry, B., Wang, J., Wu, S., Maglione, M., Mojica, W., Roth, E., Morton, S. C., \& Shekelle, P. G. (2006). Systematic review: impact of health information technology on quality, efficiency, and costs of medical care. Annals of internal medicine, 144(10), 742-752.

Dianingrum, M., \& Suryanto, A. (2014). Penentuan Status Gizi Balita Berbasis Android Menggunakan Metode Analitycal Hierarchy Process (AHP). JUITA: Jurnal Informatika, 3(1).

Erwin, P. C. (2008). The performance of local health departments: a review of the literature. Journal of public health management and practice, 14(2), E9-E18. 
Faber, M., Schoeman, S., Smuts, C. M., Adams, V., \& Ngomane, T. (2009). Evaluation of community-based growth monitoring in rural districts of the Eastern Cape and KwaZulu-Natal provinces of South Africa. South African Journal of Clinical Nutrition, 22(4).

Ford, E., Carroll, J. A., Smith, H. E., Scott, D., \& Cassell, J. A. (2016). Extracting information from the text of electronic medical records to improve case detection: a systematic review. Journal of the American Medical Informatics Association, 23(5), 1007-1015.

Ganeshkumar, P., Kumar, S. A., \& Rajoura, O. P. (2011). Evaluation of computer usage in healthcare among private practitioners of NCT Delhi. In MIE (pp. 960-964).

Guyon, A., Bock, A., Buback, L., \& Knittel, B. (2016). Mobile-based nutrition and child health monitoring to inform program development: an experience from Liberia. Global Health: Science and Practice, 4(4), 661-670.

Health, O. M. D.-G. (2015). Ensure Healthy Lives and Promote Wellbeing for All at All Ages Oslo.

Jones, S. S., Rudin, R. S., Perry, T., \& Shekelle, P. G. (2014). Health information technology: an updated systematic review with a focus on meaningful use. Annals of internal medicine, 160(1), 48-54.

Lwoga, E. (2014). Critical success factors for adoption of web-based learning management systems in Tanzania. International Journal of Education and Development using ICT, 10(1), 4-21.

Mason, J., Mebrahtu, S., \& Horjus, P. (2010). Developing nutrition information systems in Eastern and Southern Africa. Food and nutrition bulletin, 31(3), S272-S286.

Miko, A., \& Al-Rahmad, A. H. (2017). Hubungan Berat Dan Tinggi Badan Orang Tua Dengan Status Gizi Balita di Kabupaten Aceh Besar. Gizi Indonesia, 40(1), 21-34.

Nadiyah, Briawan, D., \& Martianto, D. (2014).
Faktor Risiko Stunting Pada Anak Usia 023 Bulan Di Provinsi Bali, Jawa Barat, Dan Nusa Tenggara Timur. Jurnal Gizi dan Pangan, 9 (2), 125-132.

Nidhra, S., \& Dondeti, J. (2012). Black box and white box testing techniques-a literature review. International Journal of Embedded Systems and Applications (IJESA), 2(2), 29-50.

Randell, R., Mitchell, N., Thompson, C., McCaughan, D., \& Dowding, D. (2009). Supporting nurse decision making in primary care: exploring use of and attitude to decision tools. Health Informatics Journal, 15(1), 5-16.

Sanjaya, G. Y., \& Hidayat, A. W. (2016). Pemantauan Obat dan Perbekalan Kesehatan di Indonesia: Tantangan dan Pengembangannya. Journal of Management and Pharmacy Practice, 6(2), 159-168.

Sartika, R. A. D. (2012). Penerapan komunikasi, informasi, dan edukasi gizi terhadap perilaku sarapan siswa Sekolah Dasar. Kesmas: National Public Health Journal, 7(2), 76-82.

Wajhillah, R., \& Pribadi, D. (2014). Sistem Informasi Pemantauan Tumbuh Kembang Balita Pada Posyandu Menggunakan Metode Z Score Berbasis Web (Studi Kasus: Posyandu Durian 8 Kel. Subangjaya Kota Sukabumi). SNIT 2014, l(1), 130-135.

Wardani, R. S., \& Astuti, R. (2017). Aplikasi Pemetaan Daerah Rawan Gizi dan Status Gizi Bayi dan Balita di Semarang Menggunakan Sistem Informasi Geografis (SIG). Jurnal Kesehatan Masyarakat Indonesia, 4(2), 65-73.

Weiskopf, N. G., \& Weng, C. (2013). Methods and dimensions of electronic health record data quality assessment: enabling reuse for clinical research. Journal of the American Medical Informatics Association, 20(1), 144-151. 